\title{
PROFESIONALITAS GURU SERTIFIKASI DALAM MENINGKATKAN MUTU PENDIDIKAN ANAK IBTIDAIYAH
}

\author{
DYAH PRAVITASARI \\ Email : Dyahpravitasari1@Gmail.Com \\ Prodi PGMI Program Pascasarjana Fakultas Ilmu Tarbiyah dan Keguruan \\ UIN Sunan Kalijaga
}

\begin{abstract}
Abstrak
Pemerintah telah berupaya meningkatkan kualitas pendidikan salah satunya dengan adanya program sertifikasi guru. Program sertifikasi guru merupakan upaya untuk mendapatkan guru yang profesional. Oleh karena itu guru sebagai sosok yang profesional harus memiliki kompetensi dan kinerja yang sesuai dengan tuntutan pekerjaanya sehingga mempunyai kewenangan yang jelas. Dengan adanya sertifikasi atau guru yang profesional pemerintah berharap guru dapat meningkatkan mutu pendidikan. Adapun tujuan umum dari penelitian ini adalah untuk melihat sejauhmana guru yang telah bersertifikasi di dalam meningkatkan mutu pendidikan khususnya anak Ibtidaiyah. Metode penelitian yang digunakan adalah meteode penelitian kualitatif. Berdasarkan hasil penelitian, penulis memaparkan bahwa ada beberapa guru yang belum memenuhi semua kriteria guru profesioanal, seperti belum mampu menggunakan metode pembelajaran yang efektif, kurangnya pemahaman guru terhadap penggunaan IPTEK, kurangnya kesadaran guru untuk meningkatkan kualitas dirinya dan kurangnya kesadaran guru terhadap tugas dan fungsinya sesuai dengan jabatan yang diembanya. Sehingga dengan begitu, berdampak terhadap siswa yakni minat belajar siswa menjadi kurang.
\end{abstract}

Kata Kunci: Profesionalitas Guru Sertifikasi, dan Mutu Pendidikan

\section{A. Pendahuluan}

Undang-undang Republik Indonesia Nomor 20 Tahun 2003 tentang Sistem Pendidikan Nasional pasal 39 ayat 2 menyatakan bahwa, Pendidikan merupakan tenaga profesional yang bertugas merencanakan dan melaksanakan proses pembelajaran, menilai hasil pembelajaran, melakukan pembimbingan dan pelatihan, serta melakukan penelitian dan pengabdian kepada masyarakat, terutama bagi pendidik. 
Menurut Martinis Yamin mengatakan bahwa sebagai guru yang profesional, setidaknya harus memiliki latar belakang pendidikan yang relevan dengan keahlian, dan pengalaman mengajar, penggunaan kompetensi dan kewenangan guru di ruang kelas yang meliputi: (a) menguasai bahan, (b) mengelola program belajar mengajar, (c) mengelola kelas, (d) penggunaan media/sumber, (e) menguasai landasan pendidikan, (f) mengelola interaksi belajar mengajar, (g) menilai prestasi siswa untuk kepentingan pengajaran, (h) mengenal fungsi dan program bimbingan dan penyuluhan di sekolah, (i) mengenal dan menyelenggarakan administrasi sekolah. ${ }^{1}$

Guru profesional adalah guru yang memiliki kemampuan atau keahlian khusus dalam bidang keguruan (pembelajaran), sehingga ia mampu melakukan tugas dan fungsinya sebagai seorang pengajar yang memiliki kemampuan maksimal. Dan guru profesional juga bisa disebut sebagai seorang guru yang terdidik terlatih dengan baik dan memiliki pengalaman yang kaya dibidangnya. Oleh karena itu, seorang guru profesional telah memperoleh pendidikan formal serta menguasai strategi pembelajaran dan menguasai landasan-landasan pendidikan yang tercantum dalam kompetensi.

Dominasi pendidikan di sekolah-sekolah lebih mengutamakan guru yang telah sertifikasi (guru yang profesional), hal ini terlihat perbedaan yang sangat mencolok dari kedua bentuk guru tersebut. Menurut Mulyasa guru sertifikasi merupakan proses uji kompetensi bagi calon guru atau guru yang ingin memperoleh pengakuan dan meningkatkan kompetensi sesuai profesi yang dipilihnya. Sedangkan guru yang tidak memiliki sertifikat pendidik bisa dikatakan guru yang belum profesional dalam proses pembelajaran, baik dalam segi penyampaian, metode yang digunakan serta pembuatan rencana pelaksana pembelajaran. Oleh karena itu program sertifikasi guru adalah suatu program yang dilakukan oleh pemerintah dibawah kuasa dinas pendidikan Indonesia dalam upaya meningkatkan kualitas pendidikan di Indonesia.

${ }^{1}$ Martinis Yamin, Profesionalisasi Guru \& Implementasi KTSP, (Jakarta: Gaung Persada Press,2009),hlm.135 
Salah satu usaha yang dilakukan oleh seorang guru yang profesional untuk meningkatkan pemahaman adalah memahami kriteria masing-masing peserta didik, mengenali bakat dan minat dan dapat dilanjuti dengan mengkomunikasikannya kepada masing-masing orang tua agar dapat dikembangkan baik secara formal maupun non formal. Selain itu, seorang guru juga harus senantiasa mengetahui isu-isu faktual guna untuk menambah wawasan sang guru dan dapat dijadikan pedoman dalam mendidik.

Dalam penelitian ini penulis menemukan beberapa guru yang telah sertifikasi namun belum mampu memenuhi semua kriteria guru sertifikasi dengan beberapa hambatan yang akan penulis paparkan dalam penelitian ini.

\section{B. Metode Penelitian}

Jenis penelitian ini adalah penelitian lapangan (field research), yang bersifat kualitatif, penelitian yang lebih menekankan pada pengumpulan data yang bersifat tidak berbentuk angka. Menurut Sutama, penelitian kualitatif (qualitative research) adalah penelitian yang ditujukan untuk mendeskripsikan dan menganalisis fenomena-fenomena, peristiwa, aktivitas sosial secara alamiah. ${ }^{2}$ Sumber data yang digunakan dalam penelitian ini yaitu buku, artikel, karya ilmiah dan lainnya yang relevan terhadap objek kajian pada penelitian ini. Teknik pengumpulan data pada penelitian ini adalah wawancara, dokumentasi, catatan lapangan. Selanjutnya penulis mengolah dan menganalisis data sehingga membuat kesimpulan dan mudah dipahami oleh diri sendiri maupun orang lain.

\section{Hasil dan Pembahasan}

\section{Pengertian Guru Sertifikasi}

Istilah sertifikasi dalam makna kamus berarti surat keterangan (sertifikat) dari lembaga berwenang yang diberikan kepada jenis profesi dan sekaligus pernyataan (lisensi) terhadap kelayakan profesi untuk melaksanakan tugas. Bagi guru agar dianggap baik dalam mengemban tugas profesi mendidik. Sertifikat

${ }^{2}$ Sutama, Metode Penelitian Pendidikan Kuantitatif, Kualitatif, PTK, R\&D, (Kartasura, Fairus Media,2012),hlm. 282 
pendidik tersebut diberikan kepada guru dan dosen yang telah memenuhi persyaratan. ${ }^{3}$

Secra harfiah, sertifikasi berasal dari kata certification yang berarti diploma atau pengakuan resmi terhadap kompetensi seseroang untuk memangku suatu jabatan profesional. Jika dihubungkan dengan profesi guru, sertifikasi dapat diartikan sebagai surat bukti kemampuan mengajar yang menunjukkan bahwa pemegangnya memiliki kompetensi mengajar dalam mata pelajaran, jenjang, dan bentuk pendidikan tertentu seperti yang diterangkan dalam sertifikat kompetensi tersebut. ${ }^{4}$

Berdasarkan Undang-Undang Republik Indonesia Nomor 14 Tahun 2005 tentang Guru dan Dosen pasal 1 ayat 11 menyatakan bahwa sertifikasi adalah suatu proses pemberian sertifikat untuk guru dan dosen yang telah memenuhi standar profesional guru. Guru maupun dosen yang telah memenuhi persyaratan diberikan sertifikat pendidik yang merupakan bukti formal sebagai pengakuan yang diberikan kepada guru dan dosen sebagai tenaga yang profesional. Setiap orang yang telah memperoleh sertifikat pendidik memiliki kesempatan yang sama untuk diangkat menjadi guru pada satuan pendidikan tertentu. Guru profesional merupakan syarat mutlak untuk menciptakan sistem dan praktik pendidikan yang berkualitas, sedangkan sertifikat pendidik adalah sebuah sertifikat yang ditandatangani oleh perguruan tinggi penyelenggara sertifikasi sebagai bukti formal pengakuan profesionalitas guru yang diberikan kepada guru sebagai tenaga profesional. $^{5}$

Menurut Mansur Muslich sertifikasi adalah proses pemberian sertifikat pendidik kepada guru yang telah memenuhi persyaratan tertentu,yaitu kualifikasi akademik,kompetensi, sehat jasmani rohani, serta memiliki kemampuan untuk

${ }^{3}$ Trianto \& Titik, Sertifikasi Guru Upaya Meningkatkan Kualifikasi Kompetensi dan Kesejahteraan, (Jakarta: Prestasi Pustaka,2007),hlm.11

${ }^{4}$ E Mulyasa, Uji Kompetensi dan Penilaian Kinerja Guru, (Bandung: PT Remaja Rodaskarya, 2013),hlm.30

${ }^{5}$ Jamil Suprihatiningrum, Guru Profesional, Pedoman Kinerja,Kualifikasi \& Kompetensi Guru, (Jogjakarta: AR-Ruzz Media,2013),hlm.215 
mewujudkan tujuan pendidikan nasional yang dibarengi dengan peningkatan kesejahteraan yang layak. $^{6}$

Menurut Martinis Yamin, sertifikasi adalah pemberian sertifikat pendidik untuk guru dan dosen atau bukti formal sebagai pengakuan yang diberikan kepada guru dan dosen sebagai tenaga profesional. ${ }^{7}$

Berdasarkan pengertian diatas, sertifikasi dapat diartikan sebagai suatu proses pemberian pengakuan bahwa seseorang telah memiliki kompetensi untuk melaksanakan pelayanan pendidikan pada satuan pendidikan tertentu, setelah lulus uji kompetensi yang telah diselenggarakan oleh lembaga sertifikasi. Dengan kata lain, sertifikasi guru adalah proses uji kompetensi yang dirancang untuk mengungkapkan penguasaan kompetensi seseorang sebagai landasan pemberian sertifikat pendidik.

\section{Kriteria Guru Sertifikasi}

Menurut Davis dan Thomas kriteria guru profesional yang bermutu adalah guru yang memiliki kemampuan untuk menciptakan iklim belajar di kelas, memiliki kemampuan tentang manajemen pembelajaran, memiliki kemampuan dalam memberikan umpan balik (feedback) dan penguatan (reinforcement), serta memiliki kemampuan dalam peningkatan diri. Kemampuan guru untuk menciptakan iklim belajar yang kondusif di kelas antara lain berkaitan dengan kemampuan intrapersonal, kemampuan meminimalkan permasalahan disiplin dalam pembelajaran di kelas. ${ }^{8}$

Ada lima ukuran seorang guru dinyatakan profesional. Pertama, memiliki komitmen pada siswa dan proses belajarnya. Kedua, secara mendalam menguasai bahan ajar dan cara mengajarkan ketiga bertanggung jawab memantau kemampuan belajar siswa melalui berbagai teknik evaluasi. Keempat, mampu

${ }^{6}$ Mansur Muslich, Sertifikasi Guru Menuju Profesionalisme Pendidik,(Jakarta: Bumi Aksara,2007),hlm.2

${ }^{7}$ Martinis,Yamin, Sertifikasi Profesi Keguruan di Indonesia, (Jakarta: Gaung Persada Press, 2006),hlm.2

${ }^{8}$ E Mulyasa, Uji Kompetensi dan Penilaian Kinerja Guru,hlm.30 
berfikir sistematis dalam melakukan tugas dan kelima, seyogyanya menjadi bagian dari masyarakat belajar di lingkungan profesinya. ${ }^{9}$

Dengan adanya pengukuhan guru sebagai profesi, guru dituntut untuk ikut mereformasi pendidik, memanfaatkan semaksimal mungkin sumber-sumber belajar disekolah, merombak struktur hubungan guru dan siswa, menggunakan teknologi modern dan menguasai IPTEK, kerjasama dengan teman sejawat antar sekolah, serta kerjasama dengan komunitas lingkungannya. Hal ini menunjukkan betapa tingginya tuntutan profesionalisme seorang guru.

Ciri-ciri guru profesional, antara lain: (1) guru mempunyai komitmen pada siswa dan proses pembelajarannya. Ini berarti bahwa komitmen tertinggi guru adalah kepada kepentingan siswanya, (2) guru menguasai secara mendalam bahan/mata pelajaran yang diajarkannya serta cara mengajarkannya kepada siswa, bagi guru hal ini merupakan dua hal yang tidak dapat dipisahkan, (3) guru bertanggung jawab memantau hasil belajar siswa melalui berbagai teknik evaluasi, mulai cara pengamatan berprilaku siswa sampai tes hasil belajar, (4) guru mampu berfikir secara sistematis tentang apa yang dilakukannya, dan belajar dari pengalamannya. Artinya, harus selalu ada waktu untuk guru guna mengadakan refleksi dan koreksi terhadap apa yang telah dilakukannya, (5) guru seyogyanya merupakan bagian dari masyarakat belajar dalam lingkungan profesinya. $^{10}$

Dari karakteristik atau ciri-ciri tersebut mengindikasikan bahwa menjadi seorang guru bukanlah pekerjaan yang gampang, seperti yang dibayangkan oleh sebagian orang, dengan bermodal penguasaan materi dan menyampaikan kepada siswa sudah cukup. Anggapan tersebut belumlah dapat dikategorikan sebagai guru yang memiliki pekerjaan profesional. Sebab, guru yang profesional harus memiliki berbagai keterampilan, kemampuan khusus, mencintai pekerjaannya, dan menjaga kode etik guru.

\footnotetext{
${ }^{9}$ Jamil Suprihatiningrum, Guru Profesional, Pedoman Kinerja,Kualifikasi \& Kompetensi Guru, hlm.73

${ }^{10}$ Jamil Suprihatiningrum, Guru Profesional, Pedoman Kinerja,Kualifikasi \& Kompetensi Guru,hlm.74
} 
Dengan demikian, untuk melihat apakah seorang guru dikatakan profesional atau tidak, dapat dilihat dari dua prespektif. Pertama, dilihat dari tingkat pendidikan minimal dari latar belakang pendidikan untuk jenjang sekolah tempat menjadi guru. Kedua, penguasaan guru terhadap materi bahan ajar, mengelola proses pembelajaran, mengelola siswa, melakukan tugas-tugas bimbingan dan lain-lain.

\section{Tujuan Sertifikasi Guru}

Tujuan sertifikasi guru adalah untuk meningkatkan mutu pendidikan dan profesionalitas melalui peningkatan kesejahteraan yang pada akhirnya diharapkan meningkat pula kualitas pendidikan nasional. Melalui sertifikasi guru juga diharapkan nantinya sekolah tidak hanya meluluskan peserta didik yang kemudian menjadi beban masyarakat, tetapi lulusan yang mampu mandiri, mampu menciptakan lapangan kerja dan mampu untuk melanjutkan pendidikan ke jenjang yang lebih tinggi, serta mengembangkan diri di masyarakat sesuai dengan prinsip pendidikan seumur hidup. ${ }^{11}$

Selain itu tujuan sertifikasi guru adalah untuk mengetahui apakah guru telah memiliki kemampuan profesional dan akademik yang memadai. Sertifikasi dan uji kompetensi dapat menjadi instrumen untuk standarisasi profesi guru. Dengan program sertifikasi, akan terpetakkan kemampuan guru secara nasional. Data ini dapat digunakan sebagai dasar perumusahan kebijakan, pengembangan, dan peningkatan tenaga kependidikan khususnya guru. Melalui program sertifikasi juga akan diperoleh peta kebutuhan pembinaan mutu guru sebagai dasar peningkatan kompetensi dan kualifikasi. Program sertifikasi juga diharapkan dapat menumbuhkan kreativitas, inovasi, keterampilan,kemandirian, dan tanggungjawab guru. ${ }^{12}$

\section{Pengertian Mutu Pendidikan}

Mutu adalah suatu terminologi subjektif dan relatif yang dapat diartikan dengan berbagai cara di mana setiap definisi bisa didukung oleh argumentasi yang sama baiknya. Secara luas mutu dapat diartikan sebagai agregat karakteristik dari

\footnotetext{
${ }^{11}$ E Mulyasa, Uji Kompetensi dan Penilaian Kinerja Guru,hlm.46 Guru,hlm.176

${ }^{12}$ Jamil Suprihatiningrum, Guru Profesional, Pedoman Kinerja,Kualifikasi \& Kompetensi
} 
produk atau jasa yang memuaskan kebutuhan konsumen/pelanggan. Karakteristik mutu dapat diukur secara kuantitaif dan kualitatif. Dalam pendidikan, mutu adalah suatu keberhasilan proses dan hasil belajar yang menyenangkan dan memberikan kenikmatan. Pelanggan bisa berupa mereka yang langsung menjadi penerima produk dan jasa terebut atau mereka yang nantinya akan merasakan manfaat produk atau hasil dan jasa tersebut. ${ }^{13}$

\section{Hasil Penelitian}

Berdasarkan survei dilapangan pada bulan juni 2017 total guru yang sudah melakukan sertifikasi sebanyak 308.888 guru, adapun yang belum sertifikasi terdiri atas 1.392.155. Dari data diatas dapat diketahi bahwa kuota sertifikasi guru disetiap tahunya masih minim dibandingkan dengan guru yang belum sertifikasi. Jika kita lihat perguruan tinggi di Indonesia menurut KEMENRISTEKDIKTI ada 100 perguruan tinggi yang terhitung sebagai perguruan besar di Indonesia belum termasuk perguruan tinggi suwasta, dan apabila setiap tahunya masing-masing perguruan tinggi mengeluarkan alumni lebih kurang 100 orang bisa kita bayangkan berapa banyak tenaga pendidik yang tidak diberi kesempatan menerima sertifikat guru.

Telah penulis jelaskan diatas beberapa kriteria guru sertifikasi yang harus dilaksanakan oleh yang menyandang sebagai guru profesional disekolah. Namun jika kita lihat dilapangan dari $100 \%$ guru yang telah sertifikasi bisa penulis katakan $60 \%$ guru belum mampu memenuhi semua kriteria di atas, hal ini dapat dilihat dari salah satu sekolah di Sumatera di daerah OKU Timur guru sertifikasi dalam proses belajar mengajar masih ada yang belum mampu menggunakan metode pembelajaran yang menarik, salah satu siswa disekolah tersebut mengatakan "ada salah satu guru kami yang dalam melakukan proses pembelajaran masih sangat monoton sehingga kami merasa bosan dan kurang menarik". 14

Menurut hemat penulis, beberapa faktor yang menyebabkan guru tersebut kurang menguasai metode pembelajaran adalah kurangnya pemahaman guru

\footnotetext{
${ }^{13}$ Nurfuadi, Profesionalisme Guru, (Yogyakarta: STAIN Press, 2012),hlm.152

${ }^{14}$ Hasil wawancara dengan salah satu siswa disekolah di daerah OKU Timur
} 
terhadap penggunaan IPTEK sehingga kurangnya informasi yang diperoleh serta kurang kreatif dalam berinovasi, dan kurangnya kesadaran guru untuk meningkatkan kualitas dirinya yang disebabkan oleh latar belakang tempat tinggal yang tergolong jauh dari perkotaan sehingga mereka tidak menyadari hal itu, dan kurangnya kesadaran guru terhadap tugas dan fungsinya sesuai dengan jabatan yang diembanya.

Adapun dampak dari kurangnya keprofesionalan guru tersebut mengakibatkan rendahnya semangat belajar siswa, kurangnya antusias siswa untuk mendengarkan penjelasan guru, timbulnya rasa ketidak nyamanan siswa ketika proses belajar mengajar di dalam kelas maunya keluar karena metode mengajarnya yang membuat dia bosan. Karena metode atau cara pengajarannya yang cenderung hanya memberikan tugas atau mencatat saja atau juga metode mengajarnya menggunakan metode ceramah lalu siswa-siswinya ditugaskan mencatatkan materi yang guru berikan tersebut. Tanpa memperhatikan sikologi anak yang cenderung mudah bosan karena metode yang digunakan tidak menarik dan membosankan.

Maka dengan begitu guru harus memiliki kemampuan profesional, karena kemampuan profesional sangat dibutuhkan dikalangan masyarakat khususnya dilingkungan sekolah. Karena guru merupakan orang tua yang kedua bagi siswa. Dengan guru siswa akan mendapatkan pelajaran dan ilmu, sehingga siswa termotivasi dan tertarik dengan proses belajar mengajar di sekolah. Sebaliknya apabila guru tidak memiliki kemampuan profesional, maka akan berdampak negatif dengan minat belajarnya.

Pelaksanaan sertifikasi guru ini tidak sedikit menuai badai dan hasil yang mengecewakan ketika para guru yang telah disertifikasi dan telah mendapatkan tunjangan profesi ini tidak menunjukkan kinerja yang berkualitas. Dengan kata lain, mutu guru-guru yang telah disertifikasi tidak menunjukkan peningkatan sehingga menimbulkan berbagai permasalahan di sekolah/lapangan, kecemburuan sosial dan bahkan saling lempar pekerjaan, apalagi jika yang sudah disetifikasi tersebut usianya lebih muda dari guru-guru yang ada yang belum disertifikasi. Permasalahan tersebut antara lain yang diungkapkan oleh Muslimah (Seorang 
Guru Laskar Pelangi) yang filmnya telah menggebrak dunia perfileman nasional. Dalam obrolannya, ketika penulis berkunjung ke rumahnya di Ganteng, di selasela seminar di kabupaten Belitung, beliau mengungkapkan "Guru-guru yang telah bersertifikasi tetapi tidak menunjukkan kinerja yang bermutu telah menimbulkan kesenjangan,kecemburuan sosial dan menjadi beban sekolah karena mereka mendapatkan penghasilan lebih, tetapi tidak ada peningkatan dalam kinerja". ${ }^{15}$

Ungkapan tersebut sejalan dengan persepsi para guru dan kepala sekolah diberbagai tempat dan keadaan. Semuanya bermuara pada salah satu kata, yaitu "Mutu". Itulah yang dituntut oleh dunia pendidikan kita dewasa ini, termasuk tuntutan akan perlunya guru bermutu yang memiliki nilai tambah dan daya tarik bagi peserta didik sehingga mereka mampu mengantarkan peserta didik dalam membentuk kompetensi dirinya sesuai dengan Standar Nasional Pendidikan (SNP), terutama Standar Isi (SI) dan Standar Kompetensi Lulusan (SKL) yang dijabarkan dalam Standar Kompetensi dan Kompetensi Dasar (SK-KD), dan menjadi kewajiban guru untuk mengembangkannya ke dalam indikator-indikator hasil belajar.

Pada hakikatnya program sertifikasi guru merupakan program dari pemerintah sebagai upaya untuk mendapatkan guru yang profesional. Kedudukan guru sebagai tenaga profesional berfungsi untuk mengangkat martabat guru serta perannya sebagai agen pembelajaran untuk meningkatkan mutu pendidikan nasional. Sebagai tenaga profesional tentunya guru tersebut memiliki kompetensi dalam bidangnya. Dan kompetensi yang dimaksud meliputi kompetensi pedagogik, kompetensi profesional, kompetensi sosial/personal dan kompetensi sosial.

\section{Harapan peneliti terhadap sekolah.}

Guru profesional adalah guru yang menyadari tugas dan fungsinya sesuai dengan jabatan yang diembanya, memiliki pemahaman yang tinggi serta mengenal dirinya sebagai pribadi yang dipanggil untuk mengabdikan diri kepada masyarakat melalui pendidikan dan mendampingi peserta didik belajar. Guru

${ }^{15}$ E Mulyasa, Uji Kompetensi dan Penilaian Kinerja Guru,hlm.46 
dituntut untuk belajar sepanjang hayat dan memahami karaktersitik peserta didik serta berusaha mencari tahu bagaimana seharusnya peserta didik belajar sehingga jika terdapat kegagalan dalam pelaksanaannya, guru terpanggil untuk menemukan penyebabnya dan mencari jalan keluar bersama peserta didik bukan mendiamkannya atau menyalahkannya.

Menjadi guru profesional tidak sekedar ditentukan melalui uji kompetensi dan sertifikasi karena profesi ini mengandung unsur seni dan perkara hati. Mendidik adalah seni dan profesi hati sehingga dalam pelaksanaannya hati dan naluri banyak berperan daripada budi. Oleh karena itu, pengelolaan hati yang berjiwa seni harus mendapatkan perhatian yang memadai, dengan niat dan motivasi untuk menjadi guru. Sikap yang harus senantiasa dipupuk adalah kesadaran dan kesediaan mengenal diri dan meningkatkan pemahaman mau belajar dengan meluangkan waktu untuk menjadi guru karena jika tidak bersedia belajar, tidak mungkin dapat menjadi guru profesional sehinga tidak dapat meningkatkan mutu pendidikan.

Ada beberapa harapan yang penulis berikan terhadap guru sertifikasi dan lembaganya diantaranya sebagai berikut:

1. Hendaknya kepala sekolah melakukan evaluasi diri dengan membuka lembar saran pendapat dan kritik dari stakeholder tentang pelaksanaan keprofesionalan guru sertifikasi.

2. Hendaknya kepala sekolah meningkatkan sikap positif guru dalam proses pembelajaran agar terciptanya lingkungan kerja yang baik dan hendaknya upaya-upaya menata dan meningkatkan lingkungan kerja sekolah menjadi lingkungan kerja yang kondusif bagi guru-guru dalam bertugas setiap waktunya.

3. Dan kepala sekolah mampu menjaga dan mengembangkan profesionalisme dan mutu pembelajaran pasca sertifikasi serta sepatutnya diberikan bimbingan kepada guru-guru untuk menjadikan sertifikasi guru sebagai media atau sarana untuk meningkatkan mutu pendidikan, bukan sebagai tujuan yang harus dicapai. 
4. Guru yang telah mendapatkan sertifikasi, hendaknya lebih meningkatkan kualitas diri dengan terus menambah wawasan dan kinerja dalam upaya meningkatkan mutu pendidikan

5. Hendaknya guru aktif dalam mengikuti trainning yang menyangkut keprofesionalan guru tersebut, agar lebih mampu menggunakan metode yang menarik ketika dalam proses belajar mengajar. Karena tujuan dari sertifikasi dan uji kompetensi guru adalah untuk mencapai kualitas bukan menjadi kuantitas.

6. Hendaknya guru lebih memprioritaskan siswa guna untuk meningkatkan prestasi siswa, hal tersebut dapat berdampak positif terhadap sekolah.

7. Guru sertifikasi yang belum mampu menjadi profesional dalam proses belajar mengajar kebanyakan adalah guru yang hanya memprioritaskan sertifikasi dan peningkatan karir sehingga mengakibatkan penurunan produktivitas dan kinerjanya setelah program sertifikasi dilakukan. Kedepan sebaiknya guru mengubah asumsinya bahwa sertifikasi merupakan langkah awal peningkatan kemampuan dan keterampilan profesional sebagaimana distandarkan bagi guru.

8. Kebanyakan guru mengalokasikan insentif yang diterima dari pemerintah karena telah lulus sertifikasi untuk komponen sandang pangan dan pangan. Hal ini tentu saja tidak salah, tetapi tidak proporsional jika tujuan utama program sertifikasi guru adalah untuk meningkatkan mutu pendidikan, namun dalam prosesnya tunjungan yang diterima oleh guru hanya sedikit yang dialokasikan untuk peningkatan kapasitas diri sebagai guru profesional baik secara individu maupun kelompok.

\section{Kesimpulan}

Sertifikasi merupakan sarana untuk meningkatkan kualifikasi guru guna meningkatkan mutu pendiidkan. Namun, berdasarkan hasil penelitian, penulis memaparkan bahwa sertifikasi adalah sebuah prestasi yang banyak dikejar oleh para pendidik, namun kebannyakan mereka tidak melaksanakan kewajibannya 
sebagai guru profesional. Seperti belum mampu menggunakan metode pembelajaran, kurangnya pemahaman guru terhadap penggunaan IPTEK kurangnya kesadaran guru untuk meningkatkan kualitas dirinya dan kurangnya kesadaran guru terhadap tugas dan fungsinya sesuai dengan jabatan yang diembanya. Sehingga dengan begitu, berdampak terhadap siswa yakni minat belajar siswa menjadi kurang. Selain itu juga dirasakan oleh pihak sekolah bahwa kurang produktifitas dan kurang kondusifitas lingkungan belajar disekolah tersebut.

\section{DAFTAR PUSTAKA}

Mulyasa, E, 2013, Uji Kompetensi dan Penilaian Kinerja Guru, Bandung: PT Remaja Rodaskarya

Muslich, Mansur,2007, Sertifikasi Guru Menuju Profesionalisme Pendidik, Jakarta: Bumi Aksara

Nurfuadi, 2012, Profesionalisme Guru, Yogyakarta: STAIN Press

Sutama, 2012, Metode Penelitian Pendidikan Kuantitatif, Kualitatif, PTK, R\&D, Kartasura, Fairus Media

Suprihatiningrum, Jamil,2013, Guru Profesional, Pedoman Kinerja,Kualifikasi \& Kompetensi Guru, Jogjakarta: AR-Ruzz Media

Trianto \& Titik, 2007, Sertifikasi Guru Upaya Meningkatkan Kualifikasi Kompetensi dan Kesejahteraan, Jakarta: Prestasi Pustaka

Yamin, Martinis,2009,Profesionalisasi Guru \& Implementasi KTSP, Jakarta: Gaung Persada Press

Yamin , Martinis,2006, Sertifikasi Profesi Keguruan di Indonesia, Jakarta: Gaung Persada Press

Hasil wawancara dengan salah satu siswa disekolah di daerah OKU Timur, 16 Juli 2018 